Portland State University

PDXScholar

\title{
Alina Troyano: A Proposed of Methodology for the Art Historical Analysis of a Literary Performance Artist
}

Rachel Done

Portland State University

Follow this and additional works at: https://pdxscholar.library.pdx.edu/honorstheses

Let us know how access to this document benefits you.

\section{Recommended Citation}

Done, Rachel, "Alina Troyano: A Proposed of Methodology for the Art Historical Analysis of a Literary Performance Artist" (2019). University Honors Theses. Paper 772.

https://doi.org/10.15760/honors.790

This Thesis is brought to you for free and open access. It has been accepted for inclusion in University Honors Theses by an authorized administrator of PDXScholar. Please contact us if we can make this document more accessible: pdxscholar@pdx.edu. 
Alina Troyano: A Proposed of Methodology for the Art Historical Analysis of a Literary Performance Artist.

\author{
By: Rachel G. Done \\ (donerachel6@gmail.com or rachdone@pdx.edu) \\ Thesis Advisor: Prof. Alberto McKelligan Hernández \\ 06/17/2019
}

\begin{abstract}
:
This essay analyzes performance artist Alina Troyano, aka "Carmelita Tropicana" and her performance With What Ass Does a Cockroach Sit?/¿ Con Que' Culo Se Sienta la Cucaracha? as a primary case study to show how art historians can study performance artists that defy artistic convention by having non-traditional by-products after their performances, who are more literary in nature, and therefore exist in a liminal space in the academic study of the arts. Due to that, this essay also explores the grey area of performance art in relation to performance studies and art history, and makes a clear stand to base this analysis in art historical methods such as formal analysis, even when other interdisciplinary resources and frameworks are used in order to aid in a deeper understanding of the work.
\end{abstract}


"To be a performance artist, you have to hate theatre. Theatre is fake: there is a black box, you pay for a ticket, and you sit in the dark and see somebody playing somebody else's life. The knife is not real, the blood is not real, and the emotions are not real. Performance is just the opposite: the knife is real, the blood is real, and the emotions are real. It's a very different concept. It's about true reality." -Marina Abramović ${ }^{1}$

Alina Troyano, aka "Carmelita Tropicana," is a performance artist who was born in Cuba in 1951 and immigrated to the U.S. at the age of seven. ${ }^{2}$ She is part of what is known as the 1.5 generation of Cubans who do not remember/know pre-revolutionary Cuba except through their relatives/community, but have a deep sense of longing and diaspora from it. 3 Today, she is based primarily in New York City, and often works with her sister Ela Troyano as a co-creator in other works. 4 Troyano was originally from a theatre background and started her career in the early 1980 s performing at the WOW

${ }^{1}$ Chris Wilkinson, “Noises off: What's the Difference Between Performance Art and Theatre?” The Guardian, July 20, 2010. Accessed February 20, 2019.

https://www.theguardian.com/stage/theatreblog/2010/jul/20/noises-off-performance-art-theatre. 2 The artist's legal name is Alina Troyano, but she is often referred/credited as her stage persona/alter ego Carmelita Tropicana. In interviews and performances, it is not always clear where Troyano begins and Tropicana ends to either the audience or the artist. I decided to avoid this on purpose, because my argument rests upon peeling back the layers of Troyano as an artist, and Tropicana as an extension of her, not a separate conscious entity. For the sake of clarity, I will only use the name "Tropicana" when describing her performances, direct quotes from a performance, and etc. The artist's sister Elina Troyano and friend Uzi Parnes often collaborate with her, though they are not prominently credited. Alina Troyano with Uzi Parnes and Ela Troyano. Chon A. Noriega, "Editor's Note," In I, Carmelita Tropicana: Performing Between Cultures. Bluestreak, ed. Chon A. Noriega. (Beacon Press, 2000), ix-xii. 3 Jose' Estban Muñoz, "No es fa' cil: Notes on the Negotiation of Cubanidad and Exilic Memory in Carmelita Tropicana's Milk of Amnesia,” In Drama Review (39, no.3, 1995): 76-82; Emma Pérez, "Tejanas: Diasporic Subjectivities and Post-Revolution Identities," In The Decolonial Imaginary: Writing Chicanas into History. (Indiana University Press. 1999), 77-82; Albert Sergio Laguna, "Aqui" Esta' Alvarez Guedes: Cuban choteo and the Politics of Play." In Latino Studies, (Vol. 8, 4): 516-17, 26; Chon A. Noriega, "Editor's Note," ix-xii.

4 Alina Troyano with Uzi Parnes and Ela Troyano. "Author's Introduction" In I, Carmelita Tropicana: Performing Between Cultures. Bluestreak, ed. Chon A. Noriega. (Beacon Press, 2000), xii-xxv; Marivel T. Danielson, "Our Art is Our Weapon: Identity and Representation in Queer U.S. Latina Creativity" (PhD Dissertation, University of Michigan, 2004.) 
Café Theater, an LGBT theater space. 5 This is where Troyano's stage persona Carmelita Tropicana was born, and would ultimately become the main alter-ego for Troyano. ${ }^{6}$ Troyano though has a milieu of other known characters such as: Carmelita's counterpart, the archetypal Latin macho Pingalito Betancourt, Hernando Cortes's horse and La Cucaracha Martina to name a few.7 On a very broad note, the nature of her performances usually revolve around themes of narrative, place, identity, the memory, and the constructions of these themes.

Troyano displays a form of cultural hybridity outlined by Nestor García Canlini in relation to her personal interactions and identities with the themes above and how they relate with each other. ${ }^{8}$ Scholars such as Lawrence La Fountain-Stokes, Karina Lissette Cespedes, Chon A. Noriega, and Tonya Lo' pez-Craig have labeled it as a “multi'-ness,” which is both a reference to the frequency that the artist's alter ego-Carmelita Tropicana-uses the word "multi" as suffix in her performances, as well as the readings done by scholars that state that both the artist herself and the characters she plays cannot fit neatly under one societal stereotyped label.9 As scholar Jose’ Estban Muñoz

\footnotetext{
5 Kate Davy. Triangulations. Lesbian/Gay/Queer $\boldsymbol{\Delta}$ Theater/Drama/Performance. Lady Dicks and Lesbian Brothers: Staging the Unimaginable at the WOW Café, eds. Jill Dolan and David Roman. (University of Michigan, 2010.)

${ }^{6}$ Carmelita Tropicana, "Carmelita Tropicana Unplugged," interview by David Román, The Drama Review (39, no.3, 1995): 84 .

7 Troyano, “Author's Introduction," xii-xxv.

${ }^{8} \mathrm{Ne}$ stor García Canlini, "Introduction: Hybrid Cultures in Globalized Times," In Hybrid Cultures in Globalized Times, translated by Bruce Campbell. (University of Minnesota, 2005), xxiii-xlvi.

9 C. Carr, "The Queer Frontier: Holly Hughes and Carmelita Tropicana," In On Edge: Performance at the End of the Twentieth Century. (Wesleyan University Press, 1993), 84-87; Coco Fusco, "Introduction: Latin America Performance and the Reconquista of Civil Space," In Corpus Delicti. Performance Art of the Americas, ed., Coco Fusco. (Routledge, 2000), 1-22; Jose' Estban Muñoz, "Introduction. Performing Disidentifications," "Sister Acts. Ela Troyano and Carmelita Tropicana," "Performing Disidentity. Disidentity as a Practice of Freedom," and "Latina Performance and Queer Worldmaking; or, Chusmeri a at the End of the Twentieth Century," In Disidentifications: Queer of Color and the Performance Politics. (Minneapolis: University of Minnesota Press, 1999), 1-34, 119-142, 161-200. Karina Lissette Cespedes, "Bombera on Stage: Carmelita Tropicana Speaking in Tongues Against History, Madness, Fate, and the State," In Hispanic and U.S. Latina Lesbian Expression. Tortilleras, eds., Lourdes Torres and Inmaculada Pertusa. (Temple University Press, 2003), 147-158; Tonya Lo' pez-Craig, "The Role of
} 
noted, “...Assemblages are not simply characters or personas; instead, they are something else, something multiple. An assemblage consists of lines of articulation, strata and territory, but also lines of flight and movements of deterritorialization and destratification. These lines represent different intensities and different speeds and textures. We can think of the assemblage known as Carmelita Tropicana..."10 These characters, the themes, and even the artist herself seem to operate in a liminal space. This hybridity is continued not only in the content of Troyano's performance art, but in how she does it as well. ${ }^{11}$

Carmelita Tropicana in the Performance Art of Alina Troyano," In Latina Lesbian Writers and Performers. (Haworth Press or Journal of Lesbian Studies, Vol 7, No. 3, 2003), 47-56; Noriega, "Editor's Note," ix-xii; Troyano, "Author's Introduction," xii-xxv; Carmelita Tropicana, "Carmelita Tropicana." Carmelita Tropicana's professional website, accessed November 20, 2018.

http://carmelitatropicana.com/; Leah Garland, "Introduction," and "Alina Troyano’s Performance Autobiography: The Carmelita Solution in Milk of Amnesia/Leche de Amnesia," In Contemporary Latina/o Performing Arts of Moraga, Tropicana, Fusco, and Bustamante. (Peter Lang Publishing, New York, 2009), 1-10, 45-66; Carmelita Tropicana, "With What Ass Does a Cockroach Sit?/¿ Con Que' Culo Se Sienta la Cucaracha?” In Animal Acts. Performing Species Today, eds., Una Chaudhuri and Holly Hughes. Commentary, Lawrence La Fountain-Stokes. (University of Michigan Press, 2014), 69-92. ${ }_{10}$ Tropicana, "Carmelita Tropicana," http://carmelitatropicana.com/.

${ }^{11}$ Jose' Estban Muñoz, "Choteo/Camp Style Politics: Carmelita Tropicana’s Performance of SelfEnactment," In Women and Performance: A Journal of Feminist Theory. (7, no. 2-8, no. 1, 1995): 3851; and "Introduction," "Sister Acts," "Performing Disidentity," and "Latina Performance." 1-34, 119-142, 161-200; and Danielson. "Our Art is Our Weapon;" Noriega, "Editor's Note," ix-xii; Troyano, "Author's Introduction," xii-xxv; García Canlini, "Introduction: Hybrid Cultures in Globalized Times," xxiii-xlvi; Garland, "Introduction," and "Alina Troyano's Performance," 1-10, 45-66; Davy, Staging the Unimaginable; Laguna, "Aqui' Esta' Alvarez Guedes,"516-17, 26.

I also referenced several other works to gain a reading on straddling identifications through other scholars, particularly queer and Latina, and through academic and artistic mediums. Gloria Anzaldúa, Borderlands/La Frontera. The New Mestiza. (Spinsters/Aunt Lute Book Company, San Francisco, 1987); Sue-Ellen Case, "Seduced and Abandoned: Chicanas and Lesbians in Representation," In Negotiating Performance, eds., Diana Taylor and Juan Villegas. (Duke University Press, 1994), 88-101; Mari' a Teresa Marrero, "Seduced and Abandoned: Chicanas and Lesbians in Representation," In Negotiating Performance, eds., Diana Taylor and Juan Villegas. (Duke University Press, 1994), 102-120; Coco Fusco, "Pura Bicultural: An Introduction," "Pan American Postnationalism: Another World Order," "Passionate Irreverence: The Cultural Politics of Identity," "The Other History of Intercultural Performance," In English is Broken Here. (The New Press: New York City, 1995), vii-xi, 21-64; Maya Chowdhry, "Living Performance," In Acts of Passion: Sexuality, Gender, and Performance, eds. Maya Chowdhry and Nina Rapi. (The Haworth Press, Inc., New York and London, 1998), 9-20; Nina Rapi, "Representing the 'Real," In Acts of Passion: Sexuality, Gender, and Performance, eds. Maya Chowdhry and Nina Rapi. (The Haworth Press, Inc., New York and London, 1998), 1-8; Lois Weaver, "Performing Butch/Femme Theory," In Acts of Passion: Sexuality, Gender, and Performance. (The Haworth Press, Inc., New York and London, 1998), 187-200; Pérez, "Tejanas: Diasporic Subjectivities," 77-82; Ellen M. Gil-Gomez, "Performing La Mestiza. Textual Representations of Lesbians of Color and the Negotiation of Identities," In Literary Criticism and Cultural Theory: The Interaction of Text and Society, eds., William E. Cain. 
Performance art exists in a gray zone academically between theatre studies and art history. ${ }^{12}$ In a layered and liminal sense, Troyano's works play with concepts/theories developed by scholars such as Hayden White, Jacques Lacan, and Judith Butler to make the viewer question on how they have constructed concepts like history, memory, relationships, home, identity, cubanidad, latinidad, ethnic markers, gender, class, and sexuality to name a few. ${ }^{13}$ Though these subjects are interesting and valuable when studying Troyano's work, I believe that there has not been enough attention paid to questions that arise out of studying Troyano's methodology and how this informs her work.

The main focus of this paper is to explore how art historians should study an artist like Troyano's whose process with the performance art medium is largely mediated through her literary/scholarly and Cuban-influenced rhetorical devices, and what it means for a performance artist to have largely only literary final by-products of

(Taylor \& Francis, London, 2000), 3-38, 135-166; Coco Fusco, "Preface," "The bodies that were not ours," "Bridge over troubled waters: and view from the bridge four years on," "El Último Deseo (the last wish): a performance for Cuba," "El Evento Suspendido (the postponed event): a performance for Cuba," In The Bodies That Were Not Ours and Other Writings. (Routledge, 2001), xiii-xvii, 8-17, 154-155, 163166; David Savran, "Queer Theater and the Disarticulation of Identity," In The Queerest Art: Essays on Lesbian and Gay Theater, eds., Alisa Solomon and Framji Minwalla. (New York University Press, 2002), 152-167;

${ }_{12}$ A. Melzer, "Dada Performance at the Cabaret Voltaire," In ARTFORUM (U.S.A. 12, no. 3, 1973): 74-78; Chowdhry, "Living Performance," 9-20; Nina Rapi, "Representing the 'Real.”" 1-8; Weaver. "Performing Butch/Femme Theory," 187-200; Cry a la Jack, 00:16:19, an video interview of Carmelita Tropicana, Carmelita Tropicana Collection, Hemispheric Institute Digital Video Library, New York University, uploaded 2005. Recorded at the Grimm Rosenfeld Gallery, New York, NY. Accessed January 15, 2019, http://hidvl.nyu.edu/video/sno2v98g.html; Kyle Chaka, "WTF is...Performance Art?" Hyperallergic, May 24, 2011. Accessed February 20, 2019, https://hyperallergic.com/25076/wtf-is-performance-art/; Manifest Destino, 25:44, uploaded by the New York University, Hemispheric Institute, performed by Carmelita Tropicana, ed., by Victor Bautist, at Encuentro Location (Montréal):Phi Centre, Rialto Theatre, Sala Rossa, on June 22, 24, and 28, 2014. Accessed November 21, 2018, https://hemisphericinstitute.org/en/enc14-trasnocheo/item/2441-enc14-trasnocheo-tropicanadestino.html; Khan Academy, “What is performance art?” The Tate, 2015. Accessed February 20, 2019, https://www.khanacademy.org/partner-content/tate/participation-performance/performance/a/whatis-performance-art; Wilkinson. "Noises off: What's the difference," https://www.theguardian.com/stage/theatreblog/2010/jul/20/noises-off-performance-art-theatre. 13 See footnote 12. 
her work instead of the traditionally studied material objects, such as videos, or photographs by art historians. Ultimately this inquiry aims to show how one can find varied frameworks of meaning-such as feminist, Marxist, queer, decolonial and psychoanalytic-in Troyano's work through what is primarily art historical method of a formal analysis. Hopefully, scholars of multiple academic frameworks can use the methods deployed here to study other performance artists who are strongly influenced by literature and have literary by-products after their performances.

In this paper, I will demonstrate how this can be done mainly by examining Troyano's piece, With What Ass Does a Cockroach Sit? (2013) since there are multiple prints of the script in different formats as well as some video recordings. ${ }^{14}$ When watching the performance of With What Ass Does a Cockroach Sit? I followed along with the script that is printed in Animal Acts and used this as a primary text in my analysis. ${ }^{15}$ In order to keep this essay as organized as possible I will approach the performance as linearly as I can, while simultaneously balancing my attempt to show how multiple frames of analysis can exist without necessarily contradicting the other. In doing so this will not only add to the discourse community on Troyano and show the multiple lines of inquiry one can have with performances like these, but also hopefully encourage future research into her work by art historians. In order to explore With What Ass Does a Cockroach Sit? (2013) it is necessary to provide background on the relationship between performance art and theatre, scholarship on Troyano's existing work, and the concept of hybridity in conjunction with Latinx identities and art

\footnotetext{
14 With What Ass Does a Cockroach Sit?/¿ Con Qué Culo Se Sienta la Cucaracha? YouTube video, 25:20, posted by "umichpress," uploaded February 3, 2014. Directed by David Schweizer, performed and written by Carmelita Tropicana. Performed March 22, 2013, Duderstadt Video Studio, premiered at the INTAR Theatre in 2004. Accessed November 20, 2018. https://www.youtube.com/watch?v=813L3yWZYKg ${ }_{15}$ Carmelita Tropicana, "With What Ass Does a Cockroach Sit?" 69-92.
} 
practices. After, I will go into my proposed methodology to study artists like Alina Troyano, and the nuanced meanings this can provide. This will not only add to the existing literature on Troyano and show the complexity and line of inquiry one can have with performances like these, but also hopefully encourage future research into her work by art historians.

\section{Hybridity Equates to a "Multi-ness"}

As noted earlier, Alina Troyano's work raises several questions for a wide variety of academic fields: politics, comedy, Cuban history, lesbian studies, Latin American studies, feminism, race, gender, performance studies, and several theories such as queer theory, and those proposed by Jacques Lacan, Michel Foucault, and Judith Butler. ${ }^{16}$ This is due to the artist's described "multi"-ness" or as I have described before as hybridity. The literature on Troyano has emphasized the fact that the artist allows messiness, complications, and contradictions in her work to remain unresolved. This observation by scholars is then at times treated in the wider literature as a sense of egalitarian openness on Troyano's part for being vulnerable enough with her intersectional identity to allow an audience to comment, critique, relate to, and expand their understanding of the human character. ${ }^{17}$ Though the existing literature is helpful in documenting Troyano's work and to ascertain a basic reading of this artist, I think these readings of the artist's work can at times be to simplifying of the complexity of the artists practice and work due to sheer practicality of printing space or strict academic boundaries.

\footnotetext{
16 Troyano, "Author's Introduction," xii-xxv.

${ }_{17}$ See footnote 9.
} 
One of the untouched areas of study in regards to Troyano is the surprising lack of art historical scholarship on the artist. Most of the available scholarship on Troyano examines her work through the framework of theater/performance studies. Though these performance studies resources have been extremely helpful as a large pool of the documentation of Troyano's performances, and published scripts. In particular, these studies have identified some of the culturally specific ideas/themes seen in the artist's work. But, these works do not go into the methodology of performance art or Troyano's own personal methods and how this affects/influences her work. I believe the reason that Troyano's artistic processes and by-products have largely been unexplored is due to the nonexistent analysis of her work through an art historical framework which explores such things as art practices. This lack of study may stem from the fact that Troyano's work falls under the nebulous category of performance art, which has long been a grey area of scholarship between performance studies and art history. ${ }^{18}$

Another reason Troyano has been largely ignored by the art historical canon is due to the hybridity of her production methods which includes influences from performance art, theatre, and working with her sister-with the latter two including a large amount of literary influence. This is also reflected in Troyano's by-products of her work. Unlike with works like the performance art like the happenings, Troyano almost has no documentation that her performances happened other than her scripts. By working in this way, Troyano challenges scholars by having unconventional by-products of her work that do not follow what the traditional art historical canon requires of performance art-a visual material object to study_and again with her hybridity, avoids

${ }^{18}$ See footnote 12. 
easy labeling. Meaning, Troyano has blatantly disregarded the premise of art historians critiquing works of art through categorization, which disrupts traditional art historical methods. Therefore, Troyano tangos with her alter-ego Tropicana into liminal area of art and message within an art format that has been known to snub its nose before at a sense of convention. ${ }^{19}$ This is my main argument in why I think Troyano has been studied more by performance studies scholars who are more traditionally trained to be more interdisciplinary in their scholarship versus art historians.

To be fair, even performance studies has a gap to be found in their scholarship by a lack of consideration and critical engagement with the medium of performance art in regards to Troyano's work. For one, most of the scholarship for Troyano is on her performance Milk of Amnesia.$^{20}$ Though I will agree with scholars that Milk of Amnesia is one of Troyano's seminal works for her career, there is a surprising lack of writing regarding the artist's other performances. Yet, the artist has several other works that I would argue are just as worthwhile for praise, such as With What Ass Does a Cockroach Sit?/¿ Con Qué Culo Se Sienta la Cucaracha? Upon studying this work, and adding to the existing literature on Troyano, it is apparent that works from this artist have significant cultural value and messages. Due to the nature of Troyano's work, a scholar must understand and be knowledgeable about the dialogue, or the lessons that the artist has learned from their past works, and therefore what the artist brings into their sequential works. Second, Troyano is a very literary person who continually engages with literary themes and ideas by contemporary art critics, performance artists,

\footnotetext{
19 Ibid.

${ }^{20}$ With What Ass Does a Cockroach Sit?/¿ Con Qué Culo Se Sienta la Cucaracha? Performed and written by Carmelita Tropicana. Performed March 22, 2013, Duderstadt Video Studio, https://www.youtube.com/watch?v=813L3yWZYKg.
} 
scholars, as well as poetry, Classical, and Latin American literature. ${ }^{21}$ Troyano, like artists such as Coco Fusco and Guillermo Go' mez-Peña, is an artist who takes an active role in having scholarly dialogue with academics in regards to their interpretation of her work. ${ }^{22}$ By doing so, the artist also can choose to clarify or further the blurring of any ambiguities in regards to her work. ${ }^{23}$ This is obvious in the artist's work as she writes her own scripts for all her performance, and several scholars have pointed out her puns, allusions, innuendos, and double entendres, but neither confirms of denies them in her essays and interviews. ${ }^{24}$ And finally, Troyano's love and inspiration for the written word or language is very papabile in her works and is again noted by scholars, but is not fully explored whether in regards to what literature influences her or how the written/spoken word is so much of her process. ${ }^{25}$ One of the reasons I believe this area needs more attention is because I believe this love of language is actually an influence from her Cuban heritage, and is a crucial aspect to fully understanding the implications of her performances. ${ }^{26}$

\footnotetext{
${ }^{21}$ Ibid.; Troyano. I, Carmelita Tropicana; Performative Lecture: 'Carmelita Can Be a Beast,' 00:52:40, YouTube video, posted by “UCLA Chicano Studies Research Center," June 2, 2014, takes place on April 18, 2014. Performed by Carmelita Tropicana. Recorded At the UCLA Chicano Studies Research Center. Accessed February 20, 2019, https://www.youtube.com/watch?v=P5DTW229EQE; See also footnote 41 which singles out the artist's Sor Juana influence in her works.

${ }^{22}$ Guillermo Go mez-Peña, "The Multicultural Paradigm: An Open Letter to the National Arts Community," In Negotiating Performance, eds. Diana Taylor and Juan Villegas. (Duke University Press, 1994), 17-29; Diana Taylor, "Opening Remarks," In Negotiating Performance, eds., Diana Taylor and Juan Villegas.(Duke University Press, 1994), 1-16; Coco Fusco, "Preface," "The bodies that were not ours," and "Bridge over troubled waters," xiii-xvii, 8-17, and 154-155.

23 Tropicana, "Carmelita Tropicana Unplugged: An Interview," 90; Interview with Carmelita Tropicana, oo:37:30, video interview uploaded by the New York University, Hemispheric Institute Digital Video Library as part of the Encuentro: Memory, Atrocity, and Resistance collection. Recorded in Monterrey, Mexico in 2001. Accessed January 20,2019, http://hidvl.nyu.edu/video/2547db54.html. 24 See footnote 9, but also Tropicana, "Carmelita Tropicana Unplugged: An Interview," 90. 25 See footnote 9.

${ }^{26}$ Muñoz, "Choteo/Camp Style," 38-51; And "Sister Acts. Ela Troyano and Carmelita Tropicana," and "Latina Performance,” 119-142, 161-200. Laguna, “Aqui“ Esta' Alvarez Guedes," 516-17, 26. Interview with Carmelita Tropicana, performed by Carmelita Tropicana. Recorded in Monterrey, Mexico in 2001. http://hidvl.nyu.edu/video/2547db54.html.
} 
Scholars, I think have largely taken for granted the fact Troyano is a performance artist. It is very possible that Troyano could have chosen to be an academic scholar or go on to be a writer. ${ }^{27}$ But she choose to engage in a fairly new branch of performance art that was started by radical art groups, that did not require a one to be as literature based. ${ }^{28}$ Troyano decided/wanted to engage in this art form so much, though she herself as "Alina Troyano" could not perform what she wanted to portray, that she made an alter ego in order to do so. ${ }^{29}$ This speaks volumes of an artist who is and/or was so possibly introverted, scared, unsure, and struggling with her own identity, to be so determined to put herself out there, and be vulnerable to an audience all in order to say and find what she wanted, or maybe to even be someone else for a time. That character making as an artistic process and its complications for the content Troyano covers has, I think, largely been unexplored.30

${ }_{27}^{27}$ Troyano. I, Carmelita Tropicana; A Performative Lecture: 'Carmelita Can Be a Beast,' performed by Carmelita Tropicana, https://www.youtube.com/watch?v=P5DTW229EQE; Performing Species: What Can Animal Studies and Theatre/Performance Studies Teach Each Other? 01:32:59, YouTube video, uploaded by "NYUAD Institute," on August 7,2015. Recorded on September 19, 2014. Accessed February 20, 2019, https://www.youtube.com/watch?v=7J49hw46wmo; Carmelita Tropicana and Ela Troyano: $R+D$ for Schwanze-Beast," o0:05:36, YouTube video, uploaded by “vplsara," on July 2, 2015. Accessed February 20, 2019, https://vermontperformancelab.org/current-artists/41-Residencies/carmelitatropicana; Carmelita Tropicana reads for Memories That Smell Like Gasoline: Reading David Wojnarowicz. 00:08:43, Vimeo video, posted by "Visual AIDS," in October 2018, performed by Carmelita Tropicana, filmed and ed. Kyle Croft. This program was organized in collaboration with the Whitney Museum of American Art. Accessed January 15, 2019, https://vimeo.com/292723134; "Memories That Smell Like Gasoline: Reading David Wojnarowicz," Whitney American Museum of Art. Accessed January 15, 2019, visualaids.org/events/detail/memories-that-smell-like-gasoline; Musing Muses, 00:09:59, YouTube video, posted by "TheFeMUSEum," on September 18, 2011. Recorded at Dixon Place, on May 29, 2011. Accessed January 15, 2019, https://www.youtube.com/watch?v=3TK1VQitd-M; Musing Muses Carmelita Tropicana, o0:04:57, YouTube video, posted by “TheFeMUSEum,” on September 18, 2011. Recorded at Dixon Place, on May 29, 2011. Accessed January 15, 2019, https://www.youtube.com/watch?v=zUZEdkcJiuA\&list=PL7F36C26374B35422\&index=3. See Footnote 41 for the artist's work pertaining to Sor Juana Inéz del la Cruz allusions.

${ }^{28}$ See footnote 12.

${ }^{29}$ See footnote 1,2 , and 6 .

30 See footnote 9 . 
There is also a gap in the literature in regards to the fact that Troyano herself has almost never truly professionally set foot on stage as herself, it is her alter ego/character Tropicana. Even in her published writings she is listed as "Carmelita Tropicana" most of the time, and her sister is not mentioned despite being a huge co-collaborator. ${ }^{31}$ Though this is briefly discussed in terms of the altersubject, Subject, and disidentifications in an abstract Butlerian/Foucauldian/Lacanicain way in the literature on Troyano, what does that mean practically in regards to the creative relationship that Troyano has to her work, and to the ego of Carmelita? $3^{2}$ Who is truly the creator of these performances? Who is truly doing the labor? What does Carmelita or Troyano become based on the context of who their audience is?

To summarize, Troyano's work has largely been ignored in terms of artistic medium and process which includes her Cuban influenced rhetorical devices, literary influences, final by-products, her oeuvre as a whole, and has not been properly studied through an art historical approach.

\section{Exploration and Formal Analysis of With What Ass Does a Cockroach Sit?/¿́ Con Qué Culo Se Sienta la Cucaracha? 33}

"LA Cu-ca-RA-CHA, LA Cu-ca-RA-CHA..." is sung in a traditional mariachi cadence, and sets the tone for what is about to begin. 34 Before the lights or Carmelita

\footnotetext{
${ }^{31}$ See footnote 1,2 , and 6.

$3^{2}$ Garland, "Introduction," and "Alina Troyano’s Performance," 1-10, 45-66.

33 With What Ass Does a Cockroach Sit?/¿ Con Qué Culo Se Sienta la Cucaracha? Performed and written by Carmelita Tropicana. Performed March 22, 2013, Duderstadt Video Studio, https://www.youtube.com/watch?v=813L3yWZYKg.

34 To note, I do not speak Spanish and Troyano's recorded performances are more often than not captioned. So, there may be errors in my transcription. I am at times, in order to convey the dramatic effect of the performance and cadence of speech best, spelling things phonetically, have incorrect grammar, or italicized words for emphasis.
} 
Tropicana has hit center stage this is how she has chosen to begin her performance of With What Ass Does a Cockroach Sit?/¿ Con Que’ Culo Se Sienta la Cucaracha? at the Duderstadt Video Studio in 2013. Yet, before one allows themselves to be captivated by Carmelita Tropicana's performance, an art historian must ask how they can study a performance artist such as Carmelita Tropicana? Especially, considering after the performance is over, Troyano's script is all that remains as a record, and not a visual object that is the traditional focus of art historians? As stated earlier, it is my intention to show how that can be done with the framework of an art historical formal analysis, with some interdisciplinary tools borrowed from English literature studies, and $L a$ Cucaracha as my case study. Again, when watching the performance I used the script from Animal Acts as my guide and base for analysis. 35 To note, Troyano's performances tend to be circular in narrative structure. In order to provide the most coherence to this analysis I approach the performance as linearly as I can through the format of time, but this is balanced with my attempt to show how multiple frames of analysis-such as feminist, Marxist, psychoanalytic, queer, and decolonial-can exist in La Cucaracha without necessarily contradicting the other. This will not only add to the existing literature on Troyano and show the multiple lines of inquiry one can have with performances like these, but also hopefully encourage further research into her work by art historians. After, I will go into my proposed methodology to study artists like Alina Troyano, and the deeper meanings this method can help provide analyzes. By doing so, this should add to the existing literature on performance artists who operate like Troyano, as well as shed some light on the artist's work, all while maintaining the

35 Carmelita Tropicana. "With What Ass Does a Cockroach Sit?" 69-92. 
complexity that she is known for in her work.

Carmelita Tropicana emphatically creates her presence on the stage, and her canvas to create/reveal meanings as soon as the performance starts. Costume is a vital aspect Troyano's art practice that is curated by Troyano and her collaborators to create Tropicana, content, and to size up the makeup of her audience. Carmelita continues her song referring to several different animals, as she walks out onto the stage in high platform dark glittery sandals, a black and gold metallic leopard patterned leotard, a leopard fur bolero, with a full face of makeup and classic red lipstick. With the minimal stage set and Tropicana's outfit, she is drawing attention to her as an image/object of what some would imagine to be a more modern loud-trashy kitschy-Cuban stereotype, or as Jose Estban Muñoz would say chusma, instead of the classic Carmen Miranda image when thinking of Cuban women. ${ }^{36}$ The artist is purposely performing the identity of a Cuban stereotype. Though, even here she subversively interrupts this image, the male gaze, and heterosexual desire because both Troyano and Tropicana identify as lesbians. 37 The only other objects on stage with her is a tall legged pine chair, a microphone, and a music stand. In her trademark heavy Spanish accent and slightly broken English, she cleverly uses the song to gauge how many Latinos are in the audience.

From the start of the performance, Troyano makes clear the literary hybridity of her practice, as it sets up how meaning will be constructed and interpreted for the rest of

${ }^{36}$ Amalia Mesa-Bains, "Domesticana: the Sensibility of Chicana Rasquache," In Aztlan: A Journal of Chicano Studies. (Los Angeles, 24, no. 2, Fall, 1999): 157-167; The Muses, o0:13:38, uploaded by the New York University, Hemispheric Institute, performed by Carmelita Tropicana, ed., by Victor Bautist. Performed at Sesc Vila Mariana - Acesso Balcão do Teatro on January 16, 2013. Accessed November 21, 2018.https://hemisphericinstitute.org/en/enc13-performances1/item/1999-enc13-carmelita-muses.html 37 Troyano, "Author's Introduction," xii-xxv; and Garland, "Introduction," and "Alina Troyano's Performance," 1-10, 45-66." 
the performance. She "very, very quickly" explains the story of Perez y Martina with a very Shakespearian line: a "love that dared not speak its name between a cockroach and a mouse." 38 As she talks, she is holding for display a children's illustrated book of the story by Pura Belpré, the first Latina and Puerto Rican librarian for the New York City Public Library. ${ }^{39}$ This book is too specific to have been randomly selected by the artist, and most likely would have been the first books she as child would have read and perhaps found a familiar site when she immigrated to the U.S. in a world that she described as "American milk" in Milk of Amnesia. $4^{\circ}$ Also, it cannot be understated the importance of the author of Perez y Martina being female. Seen in conjunction with Troyano's fixation of the author Sor Juana Inés del la Cruz in previous performances, it would make sense that another female author would be chosen as inspiration for the artist. ${ }^{11} \mathrm{~A}$ Children's book format is also a wise frame for a narrative. Children's books are used simultaneously as devices of entertainment and education, which provides a perfect tone and format to set for the rest of Troyano's performance as Tropicana. It sets the audience at ease naturally, until the moments of disquiet start to weave themselves

\footnotetext{
${ }^{38}$ Tropicana has always been very fast talking and in a hurry, but it also serves as a characterization of the cockroaches since they "scurry" around.

39 The book was published in 1932, it was the first Spanish language book for children published by a mainstream U.S. press. Illustrated by Carlos Sanchez. Nedua Ulaby, "How NYC's First Puerto Rican Librarian Brought Spanish To The Shelves," National Public Radio, September 8, 2016. Accessed February 15, 2019, https://www.npr.org/2016/09/08/492957864/how-nycs-first-puerto-rican-librarianbrought-spanish-to-the-shelves; "Welcome to the Pura Belpré Award home page!" Association for Library Service to Children, A Division of The American Library Association, http://www.ala.org/alsc/awardsgrants/bookmedia/belpremedal. 40 Garland, "Introduction," and “Alina Troyano's Performance,” 1-10, 45-66.

${ }^{41}$ The Muses, performed by Tropicana, ed., Victor Bautista. https://hemisphericinstitute.org/en/enc13-performances1/item/1999-enc13-carmelita-muses.html; Manifest Destino, performed Tropicana, ed., Bautista.; https://hemisphericinstitute.org/en/enc14trasnocheo/item/2441-enc14-trasnocheo-tropicana-destino.html; Carmelita Cabaret Hemi 2013, uploaded by the Hemispheric Institute, New York University. Performed by Carmelita Tropicana. Edited by Victor Bautista. Performed at SP Escola de Teatro. Performed on January 19, 2013. Accessed January 15, 2019, https://hemisphericinstitute.org/en/enc13-trasnocheo/item/2132-enc13-trasnocheocarmelita.html.
} 
as seen later on, and that is wear meaning will become apparent to the audience.

Here Tropicana starts to set up the analogy and metaphors for the rest of the performance as she explains the synopsis of Perez $y$ Martina, as well as inform the audience of the backstory of the central character, Martina, in her performance. As the story goes, Martina is a cockroach who is "very pretty" and lives in Spain, and who is extremely clean since she does nothing but clean all the time. Already, Martina is set apart by being an atypical cockroach, since roaches are usually affiliated with the image of uncleanliness. The cockroach for Tropicana's performance is to represent brown bodies, and lower-class individuals, taken in conjunction with Tropicana's later removal of her shoes. This is proven with the next remark, "One day she finds a coin, And well, what would she buy is she's a cockroach? Facepowder, of course!" Facepowder traditionally has acted as a cosmetic symbol for whitewashing individuals that can be afforded by the middle to high class. Even in the retelling of a preformatted story, Tropicana emphasizes qualifiers that are meant to make-for better lack of words-a 'lower' and 'undesirable' character into someone who is worthy of attention, both in objecthood and respectability, as well as for the audience and the other characters in the story.

Troyano though is careful to not give the audience a flat view of Martina, and therefore the symbolism Martina represents. After Martina has become beautiful and a high-class male-desired object, following a very traditional folktale format, the cockroach has a test for her potential suitors that will show that they meet a requirement of hers. "She has to ask, how they will talk to her... And if they talk nice, she's gonna marry one of them." Contrary to the previous emphasis, now the story is focusing on Martina's personhood, and not objecthood. She wants to be treated nicely 
like any other person would.

The artist is also deliberate in her use of choteo, a traditionally male form of Cuban humor, to assert a cultural hybridity, superiority to her audience, and even as a class marker. A Duck is Martina's first suitor, who to follow the narrative rules of three in storytelling, is rejected. $4^{2} \mathrm{~A}$ frog is next, who goes "barum barum barum barum, or," as Tropicana translates, "in English, it would be ribbit, ribbit, ribbit." Martina rejects him on the basis that he would never shut up, and it'd drive her crazy. Next comes the rooster, and Martina asks the same question. "And the rooster goes, Ki-ki-ri-kí," as Tropicana clarifies, "cuz it's a Spanish rooster. The American rooster will go cock-adoodle-doo." Martina rejects the rooster for the same reason the frog was turned away. Finally, now that the three suitors have been rejected the heroine's prince charming "a small raton Perez" comes forward, "who everyone believes is a full. blooded.royal. mouse, who knows how to curtsey very well.” Martina likes how Perez answers her question, they fall in love and get married. Only noticeable to someone paying close attention, Tropicana does not translate the sounds Perez makes into an English equivalent like she did with the other suitors. This is, combined with how Perez is described, subtly serves as a marker of class distinction. Now Perez as a character has been established like Martina to be equal in class markers. This garners her affection and audience's attention.

Troyano continues to establish her "validity" as a storyteller, and cements her literary influence as she concludes the story. At this point, Tropicana opens and holds up the book to show the illustrations of Martina, such as doing flamenco at the wedding.

$4^{2}$ No reason for this is given in the performance. 
Tropicana continues to reference the book by thumbing through it and intermittently holding illustrations up for view, giving the audience a sense of empirical-ness to her recounting of the story, because unless the audience has heard this story before, she could be lying, and no one would know. She relays that in the end Perez falls into a dish and boils to death. In the end, Martina becomes a widow.

One of the first moments of disquiet, or the "moral learning" that happens in the format Children's books or folktales unfolds as Tropicana concludes her introduction. "I know!" Tropicana says abashedly to the audiences shocked reaction to the ending of Perez y Martina. "This is what they tell to children before they go to bed...But it is a beautiful story that we tell the children of Latin America. It is very well known.” Tropicana ends matter of factly and assuredly. Tropicana's statement puts the audience in the very interesting position. Should this be a story they should have known beforehand? Are they uncultured compared to children in Latin America? This line of question is supported by her earlier act choteo of the translations from Spanish to English with the animal noises, and her empirical manner with the book. But before one can sit to long with these questions, she then launches into an explanation that the rest of her performance is based on the story of Elián González's story, who at the age of five was the sole survivor of a shipwreck and found at sea while trying to illegally immigrate from Cuba to Florida. The ensuing custody battle caused an international crisis between the U.S. and Cuba.43

\footnotetext{
43 "A Chronology of the Elian Gonzales Saga," Oregon Public Broadcast: a Division of Public Broadcast Service. Accessed March 16, 2019, https://www.pbs.org/wgbh/pages/frontline/shows/elian/etc/eliancron.html; Ernesto Londõno, "Increasingly Visible, Cuba's Elián González Champions Island's Government," New York Times, July 9, 2015. Accessed March 16, 2019, https://takingnote.blogs.nytimes.com/2015/07/09/increasingly-visiblecubas-elian-gonzalez-champions-islandsgovernment/?rref=collection\%2Ftimestopic\%2FGonzalez\%2C\%20Elian\&action=click\&contentCollection
} 
As a scholar, one cannot understate that even in this last bit of the beginning of Tropicana’s performance she said, “Besides Kafka’s Metamorphosis, Joan Didion’s Miami, and George Orwell's Animal Farm, Perez y Martina was one of my inspirations..." in order to clearly outline performance. 44 The literature influence is obvious here in La Cucaracha. If one pays attention, they will see that Tropicana uses the framework/method of Metamorphosis and Animal Farm to turn into a cockroach, as well as the anamorphic metaphor of satire for several different kinds of "types" of people, and the backstory of Perez y Martina, which will all serve as a foil for the political commentary of Miami and Troyano's own thoughts on the story of Elián. When "starting" her performance-though I argue she started performing as soon as she started singing-she states, "I will try like Translafsky, to become a cockroach. Can you tell I'm a Cuban cockroach?” She shimmies her whole body suggestively and smiles rakishly.

Tropicana has now taken the character Martina from the context of Spain and into Cuba, and has transformed her into one of a less proprietary in nature to intensify the symbolism that Martina had naturally in Perez y Martina, which is ultimately related to Marxism, feminism and decolonization readings. "But I am not feeling so cucaracha today." Now away from the microphone and near the chair, Tropicana looks at the audience perplexed and troubled. "I don't know why, but you know what I think?" Her face relaxes in understanding and assurity. She points to her feet. "Los zapatos. The

=timestopics\&region $=$ stream\&module=stream unit\&version=latest\&contentPlacement=2\&pgtype=colle ction

44 With What Ass Does a Cockroach Sit?/¿ Con Qué Culo Se Sienta la Cucaracha? Performed and written by Carmelita Tropicana. Performed March 22, 2013, Duderstadt Video Studio, https://www.youtube.com/watch?v=813L3yWZYKg. 
shoes.” Now barefoot, "Now that's more cucaracha, right?” Again, Tropicana is making another statement about class. Shoes have long been a symbol of class and sophistication, particularly with women. Simultaneously, Tropicana has removed the predesigned character of Martina's virtue of cleanliness, a decolonial move, and Tropicana's own personhood into an animal by the loss of her shoes to show the methods of the Metamorphosis.

These themes are present in Martina's first monologue. Tropicana stoops behind the chair to look at the audience through the slats of the chair her hands held out palms to them. Tropicana has now become Martina. "Quick, hide. Quick, hide! That should be my name, not Martina. That's what should be on my tombstone, here lies Quick Hide. The life of a cucaracha is really tough." She swaggers out from behind the chair.

"People think we're dirty. But what do they expect when we gotta hide all the time? Inside a greasy stove, under a dresser with a dust bunny the size of a bullfrog. And only if you're really lucky, behind a can of Planters peanuts that has been opened," an obvious look of pleasure crosses her face, "and can lick the salt. We suffer so much anxiety. You gotta have eyes in the back of your head 'cuz you never know where the dangers coming from.

But, I shouldn't complain, this is a good family situation for me... And Catalina, my best friend, is a very, generous, parrot, but very bossy. OOOooooo! I gotta do all her work 'cuz I got six legs, she's got two, and she's got to be inside her cage.

... And she's so strict with me. We gotta have vocabulary lessons at 12 before lunch, and then at 3 café con leche - café con leche -and not just regular café con leche, but café con leche with a discussion. And she get upset with me if I don't say something she don't wanna hear. Mira! Like my grandfather use to say [Spanish phrase.] 'You don't tell the King what he don't wanna hear."”

In her intro monologue, Tropicana has now set the stage for Martina's and Catalina's individual status's, the relationship between the two, which serves as a 
site of decolonization and Marxism again, but also arguably White feminism and other forms of it. Martina stands for the lower-class seemingly unrefined immigrant who is 'friends with' and works for the higher-class figure that is represented by Catalina, arguably the white or white passing feminist figure. Martina is humble and grateful for what she has, but is obviously settling as evidenced from her monologue and not as happy as she could be. On an Orwellian note, it is also something to note that Catalina is a parrot. A natural predator for an insect like Martina. Though not explicitly expressed in this performance there is a power dynamic of survival and power that Catalina holds over Martina. Yet-contrary to the fact Catalina has this power over Martinathere is a check system present in the form of Catalina must keep in her cage. But, this seems to be a weird self-imposed limit since Catalina is a bird that can fly, but she is choosing to stay in the cage even when her 'old man' is not at home. Catalina seems to serve as a second type of character: the one that self-imposes constraints on herself because she relies on a man for her happiness and/or sense of identity, so she sacrifices and/or views herself confined to actions that please him.

Tropicana further sets up the character of Catalina as a vehicle for feminism and decolonization, yet adds a lens of hybridity. "Cucka-roo! Cucka-roo!" She continues to make several different cawing noises having a Spanish accent to her sounds. "Practice makes perfect. Very fontisma," Tropicana remarks fondly to the audience now as the character Catalina, who has a noticeably less Spanish accented and more enunciated speech pattern than Martina. "Where is Martina? I have never met a la cucaracha more resistant." Catalina's voice almost sounds more American New England proper with her 
Spanish accent mostly making its appearance on trilling r's. "Any type of intellectual stimulation is like a punishment. How many times have I told her we must feed our brains as well as our souls? And to think. I was once like her! La salvaje. A wild savage.” Catalina has already been established as the higher-class figure, but this archetype is further refined to one of the bourgeois who was once a low-class individual that has now been 're-educated.' This is reinforced by another reference to literature that is made through the act of learning vocabulary. Catalina's character gets even more complexity as she continues in a haughty way, "I was not born in Havana, but some have called me, la senora [Spanish.] No. This grande dame was born in the jungle, and taken by a man who even took even Cuban parrots to sell in the black market. And that's how my brother, Francisco, now Harry, ended up in Chicago." Catalina re-education follows the model of white washing, as evidence of her brother's name change.

Seen in Catalina's monologue about the old man, there is a reveal of how her reeducation also points to a disturbing undercurrent of impropriety of animal-human, and for some a young-old age difference, that is common to see in areas of class difference and colonization. But it is interesting to see these differences highlighted with Catalina's bestiality. A similar effect is seen when reading Animal Farm. The scene makes the audience ask, do we as a society and an audience view human women in the same situation just as sub-human as Catalina is? Do we question if her feelings are real or is she just lying to herself? Tropicana makes the audiences questions multiply when Catalina suddenly takes on a self-righteous air. "My old man and I, we're going to be doing a duet together of a CD. And that's why I work hard, to elevate myself everyday, and learn a new vocabulary word everyday." The audience knows that this is simply not true and feels sympathy for the bird. Catalina's life and sense of happiness is built on a 
false reality. A character that at first the audience may have wanted to dislike, is now pitied. With a sense of foreshadowing, Catalina shares very matter-of-factly, "Yesterday's word was suc-cinct." This last line is a literary understatement to the situation and complexity of Catalina's situation.

Catalina presents an interesting contradiction of internalized colonization and colonizer, and victim and oppressor. Her status as a female is what I believe garners sympathy for her character from the audience. If Catalina was a male parrot, I am sure the audience wouldn't be as sympathetic. However, whatever amount of sympathy the parrot may have garnered from the audience is short lived. "Martina should be happy. How many roaches are there that learn vocabulary," (the words could almost be replaced with reading) Catalina eyes half close in a look of savoring, "and live in such splendor. A cage that's an exact replica of the Palace of Versailles. My Mirrors!" She gestures to each object. "My Luis catorce chair! And my, divan. Most people are hungry in Cuba." She gets a regal tone to her voice. "I am like Marie Antoinette. I say, let them eat cake!" She caws, what I assume is the Spanish equivalent phrase twice. The audience is now reminded why they didn't like Catalina in the first place. Yet, the reference to Marie Antoinette conjures some interesting images and references up of females in power, yet subservient to male controlled powers and set limits. Catalina starts their vocabulary lesson after Martina has done her bidding of checking on the old man. The day's word is petit pois, which is French for peas. The word serves as another bourgeois reference, that is even more apparent after the Marie Antoinette reference. Before Martina leaves to visit the apartment below where Lumumba the Lizard resides, Catalina reminds Martina to be back for café con leche on the topic on "Spain becoming the biggest investor in the Cuban economy" which serves as another reference to 
Martina's past. This serves as foreshadowing for the following scene.

Tropicana, even with transition scenes, uses the opportunity to build upon the symbolism of Martina as she describes her old living situation in the apartment downstairs, "To think, I use to live in this apartment! This, was a very bad family situation for me. A lot of danger, and no food! One week, I was on a strict diet of hair. Hair is so bad for the digestion!" This is a reference to the Metamorphosis, where the cockroach slowly starved to death. Story wise, it would also make sense for Troyano to put her narrative both figuratively and literally "in the apartment” above Kafka's since her character is more complex and encompassing in symbolism and has actually managed to survive.

For Tropicana, the next site of production for meaning comes when Martina meets Elián. A conversation between the cockroach and the child unfolds one-sided, when Martina's antenna has been caught by a child. "What, you're a good boy, and you gotta kill me 'cuz nobody likes roaches in the house, they're dirty." The analogy of Martina's status as a lower class is brought back to the audience's attention. She continues pleading that cockroaches being dirty is a lie.

Elián, in La Cucaracha becomes a metaphor for the larger world and the state of Cuba simultaneously in a purely Marxist and colonial manner. Pausing tentatively, "You're a good boy and don't lie, and you like to play with the tourist children at the hotel, where your father works. But the tourist children got bigger, better toys than you, a power ranger and an SUV." She tries to brighten up her previously troubled tone, "But you got toys that are magic, a rock and a stick, and they can fly." She looks dubiously sarcastic, “Oo, you're a smart boy!” Troyano as a writer has managed to very beautifully turn this scene where Martina's interaction with the boy is not so subtle reminder of the 
economic situation in Cuba. Perhaps for some of the audience this performance may have seemed minutely subversive in its commentary, but largely existing and taking place in its own world in which the apartment Catalina and Martina share. Hearing of this little boy's situation and the toxic tourism with its inherent disparities between visitor and native bring the audience back to reality to ultimately what the story is about, the boy Elián and his immigration.

Yet, just like with Catalina, Elián represents a complex symbolism, particularly in regards to Marxism and globalization. As much as he is a victim of capitalism, already at such a young age, is already an agent of it. What sympathy the audience had for Elián disappears with the line, "So bye bye dirty roach, I kill you." Which is markedly the only time Tropicana gives a direct voice to Elián by assuming his role speaks the whole performance. Even after all of the common ground Martina has reached for with Elián, the boy is still full of prejudice for her marked class difference of being marked "dirty." It's only until Martina says she is friends with the "Queen" that the boy stops his attempt to kill her.

This provides an interesting site to study about the construction of concepts like memory, identity, and validity, which are common themes for Troyano's work. After making Martina promise not to run away, Elián lets go of Martina's antenna and she brings back the backstory in Perez y Martina with some exaggeration. Or is it? Martina recounts that she was the best flamenco dancer in all of Cuba, and that's how she got to be the "roach-in-waiting" to the Queen of Spain. With the framing of the scene, and Tropicana's tonality, it is no longer clear here whether Martina is fabricating this story for Elián to save herself, or if she is remembering her past as Martina in Perez $y$ Martina. As the roach recounts her dancing, she is interrupted by questions one would 
expect any five-year-old to ask, but we only hear Martina's answers like, “A crown, yeah but she doesn't wanna wear...a crown 'cuz she wants to be more demo-crat-ic. No, more communist. No, more capital," grumbling in frustration, "Look the parrot has got me mixed up, okay," the roach says as she tries to justify earlier her confusion over politics. This is not a subtle comment on not only how confusing the constantly worlds politics are, but especially Cuba's complicated political history has been for the last 100 years, and its corresponding identity. This is a reflection of the confusion that has been associated to the feelings people belonging, like Troyano, to the 1.5 generation of the Cuban diaspora, which was the focus of her performance Milk of Amnesia. 45

Yet, unlike Milk of Amnesia, and despite the performance being inspired by a Children's book, and the presence of talking animals, Tropicana keeps the story grounded in a sense of reality that is reminiscent of the structures that frame Animal Farm, and several other satires. At one point, Elián interrupts Martian and says he wants to kiss her so she'll turn into a princess. She starts to rebuff him saying that that only happens in fairy tales. It is unclear here whether this is commentary on Tropicana's sexuality, a feminist/realistic angle, or a classicist remark. Other people enter the room so Elián lets Martina escape. Though the audience feels relieved and happy that Martina escaped, one feels see sad because one can infer that Elián saved her because he likes her, but due to the Marxist reading there is is doubt in the audience's mind. Did Elián in reality save her just because she told him for her accomplishments? Or did he spare her because Elián genuinely likes Martina?

Craft wise, Troyano seems to put the densest scenes to unpack in monologues by

45 See footnote 3. 
the characters. Martina's second monologue in la Cucaracha serves to show commentary on the careful symbolism that has been built in this world by an Orwellian means.

"But life is good for me here. All I gotta do is shut up. I am getting good at climbing..." Smacking her lips, "I could use a little contemplating.” Sighing contently, “There is nothing more relaxing than contemplating on top of a postcard. My favorite day is Rio de Janeiro, where Yemaya has there feast day. I love Yemaya because she respects roaches. Thank you, Yemaya for not letting Elián believe I was a dirty, dumb, disgusting cockroach. Contemplating is good."

Sighing again Tropicana swings her arms with her palms facing out and her legs turned outwards, "We roaches, we are bumpy bugs. The bees and the ants, they're the workaholics." Proudly she continues, "We love to contemplate, yeah... Ayy. Sometimes, I don't understand why people hate us so much? We've been in this planet since the day of the dinosaur. And we, are not extinct, why??? Cuz...," she thinks about it, “... we outsmart people and we're easy going.” Indignant, “How many times they hit us with a broom? And then they go find a pan or a newspaper to pick the cadaver up and SURPRISE!!” Her legs pump out with energy. "Then they yell, 'Conyo! Where did that maldita cucaracha go?!' Martina taps her temple and nods sagely to the audience, "We outsmart people, yeah." Passionately she continues, "We live. We are survivors. We live, even if our lives are full of insult!" Out of all the monologues in this performance, this one may be the most interesting one.

With the previous idea that the role of the cockroach metaphorically stands in for the role of the lower-class/indigenous/uncultured/object of prey/immigrant versus another character like Catalina who is the opposite of the aforementioned labels accepted, this monologue becomes a testament to culture, power, wisdom, and intellect on the part of the cockroach. The narrative foil that Troyano has built through her literary influences, particularly Animal Farm, has paid off. 
There is a suggestion of social climbing on Martina's part, but she uses the word "contemplating," meaning if she did any kind of climbing she did it on her own intellectual designs and merits.

It also seems to outline the cultural difference between Martina as a cockroach who is contemplative as a characteristic, and other insects like "bees and ants." I would suggest that this comparison is a metaphor for a larger cultural one between countries like the U.S. and other Latin American countries. In the U.S. currently, one has only to turn on the news or social media to see racism against Latinxs both in and outside of the country for their perceived criminality and laziness, especially with the presidency of Donald Trump. ${ }^{46}$ This distaste and racist views are further articulated in Martina's metaphor as she addresses the sheer amount of survival that cockroaches have to go through to exist in the world. Here again the decolonizational aspect comes into Troyano's work when one remembers that when Martina states that roaches have been around since the dinosaurs, she is in fact correct. As an audience member, it is natural to start asking oneself questions such as: why do such creatures like roaches, who have more than proven their right to existence, need to constantly prove their worth as the "other" to humans? Why aren't humans in the position of the "other" considering how long roaches have been around? Why do humans get to weave this tale of extinction and uncleanliness about cockroaches, when it is obvious when looking at Martina that tale is just simply not true? Shouldn't humans

${ }^{46}$ Mark Hugo Lopes, Ana Gonzales-Barrera and Jens Manuel Krogstad, "2. Latinos and discrimination: More Latinos have Serious Concerns about their Place in America under Trump," Pews Research Center: Hispanic Trends, October 25, 2018. Accessed January 15, 2019, https://www.pewhispanic.org/2018/10/25/latinos-and-discrimination/ 
respect such a long standing culture and species such as this? The issue becomes, will/would the audience connect these lines of inquiry and morality to Latinxs and First Nation Peoples?

Catalina offers the next monologue to analyze when she recounts the immigration of 14 people leaving Cuba by boat. "The last passengers, were El Nino and his mother, five years old." This passage is interesting since it shows themes of globalization, the construction of hybridity, commentary of politics , in particular LGTB+ rights, and Marxism. As the audience listens to Catalina, they hear a tale that perhaps they know of abstractly by what they hear on the news, but the reality becomes more apparent as the parrot goes on. An interesting cross-cultural dialogue happens here as Catalina continues to highlight the hybridity of the 1.5 generation of Cubans. She tells how both the boy and mother had moments of hesitation in embarking on the trip, but they both pressed on and boarded the boat for the sake of their 'future.' The little boy tried to be brave, but when he couldn't see the lights of his home due to the crowd he couldn't overcome his sense of loss and sadness. To distract the boy, the mother tried to point out the planets. "She wasn't remotely correct" in her identifications, but it did distract him. She sings to her child, When I Wish Upon a Star. 47

The disidentifications of the stars one could read it several ways, both in a very straightforward literal sense, or as typical of Troyano's work, a way that points to the liminal spaces between reality and the construction of it in a very psychoanalytic manner. One, in the literal sense the mother is uneducated due to the Cuban system.

47 Cliff Edwards, "When I Wish Upon a Star," by Leigh Harline, Ned Washington, in Pinocchio, Walt Disney Studios, 1940; Ben Sharpsteen and Hamilton Luske. Pinocchio, February 23, 1940. (Los Angeles, Walt Disney Studios and RKO Radio Picture 
Two, in the liminal sense since stars have long been used as a form of navigation it could be seen that the path is unclear even to the mother, though as the adult in this scenario the audience would hope that she would know the way. This builds the consequence and metaphor that our children as individuals and a society-represented in this case by Elián-follow the path that the adults in their life point out. As children, society in general often find these paths represented in books and movies, even simple ones like Perez y Martina or Pinocchio. ${ }^{48}$ It is only when it is too late that most grown adults realize that the adults they grew up following may have been themselves mislabeled and lost while on the path. The question becomes if they will stay on the course they thought was set for them or will/can they change their mind? This decision process is mirrored by the analogy of the night sky, and all the countless paths to be had among the stars. This direct lesson echoes back to when Elián's mother hesitated about getting on the boat. Though she knew she could die by immigrating this way, as several had done before her, she still chose to embark on this path. Third, it shows the cross-cultural fertilization between Cuba and America, and the myth of America. When I Wish Upon a Star is an American classic, made by the media conglomerate of Disney Studios. This song, especially in this context, shows the myth that dreams can become more likely in America, and that a little boy can become a 'real' one. 49

The last and maybe most amusing part of the performance to unpack is Troyano's Orwellian creation of two female dolphins that comments on LGBT+ and their rights to adopt, and also the idea of performativity. Martina becomes rightly sad about the boy's fate of losing his family, but Catalina assures her that the story churns from a tragedy

\footnotetext{
${ }^{8}$ Ben Sharpsteen and Hamilton Luske, Pinocchio, 1940.

49 The whole goal of the story of Pinocchio is for the puppet-boy to become a "real"-boy.
} 
into a comedy as two female dolphins, Dolores and Dominique, rescue the boy. The two dolphins and the boy grieved together for their own loses of either their mothers or children. "Then after they cried, they pirouetted, and echo located." From the way that Tropicana performs this line, the scene is set that these characters are gay. This is made clear with the comment, "Imagine, a boy with two mommies. But the sharks vetoed the adoption." So, the dolphins found a fishing boat and pushed Elián to the crew so he could be picked up. With this performance being made and done before gay marriage was legal in the U.S. this scene in not only humorous, but is an obvious commentary on LGBTQ+ rights and ideas of same sex couples in regards to parenthood. $5^{\circ}$ Thinking in regards to Troyano's influence of Animal Farm, and the deliberateness George Orwell used in picking certain animals to represent certain people for his satire, the dolphin and shark are very interesting animals to choose for this scene. Dolphins are not only known for their history of interactions with saving people at sea, but are also one of the few animals that are "known" to have pleasure while having sex, to have it quite frequently for non-reproductive purposes, are mammals, and are extremely intelligent creatures with brains that are similar in size to humans. ${ }^{11} \mathrm{~A}$ lot of these factors can serve as the basis for an argument for dolphins sharing very human characteristics. The sexual tendencies of these dolphins can also be seen as a way to refute some of the right-wing

\footnotetext{
${ }^{50}$ Same-sex being able to adopt was only made legal in 2016 all fifty states in the U.S. So, both when the performance premiered and when this iteration was performed, same-sex adoption was not a guarantee. Mollie Reilly, "Same-Sex Couples Can Now Adopt Children In All 50 States," Huffington Post, March 31, 2016. Accessed January 20, 2019, https://www.huffpost.com/entry/mississippi-same-sexadoption n 56fdb1a3e4b083f5c607567f “Can Same-Sex Couples Adopt?” American Adoptions. Accessed January 15, 2019, https://www.americanadoptions.com/adopt/LGBT adoption 51 "Why are people and dolphins the only mammals that have sex for pleasure?" University of California, January 20, 2006. Accessed March 15, 2019. http://scienceline.ucsb.edu/getkey.php?key=1132; Cara Santa Maria, “Is Sex For Pleasure Uniquely Human?” Huffington Post, January 13, 2012. Accessed January 20, 2019. https://www.huffpost.com/entry/sex-for-pleasure_n_1090811
} 
religious leaders' comments about queer sexuality and rights. Sharks though intelligent, are top of the food chain predators, and hold an image for being vicious due to films like Jaws by Steven Spielberg in $1975.5^{2}$ They also can be very cannibalistic, especially towards their young, and aren't even mammals, therefore not sharing very human traits.53 When considering these factors, it can be an eyebrow raising sensibility that takes over the audience when addressing the concept that a ruling body of vicious fish makes decisions of such a personal matter for intelligent mammals like dolphins.

Tropicana finishes the performance with a great reminder for how often one as an audience can become desensitized to media, and forget that most of the stories we come across the news are happening to real people. When Catalina had first started telling the story, Martina had been anticipatory for a 'good' tragedy story, like gossip. But, when Martina recognizes the name she becomes crestfallen. She remarks to Catalina, "I know him. This is not news. This is a real tragedy! I know him."

Tropicana finishes the story by informing the audience that Elián was ultimately sent back to Cuba. But between then and there, Martina and Catalina had a huge fight and during it the roach ends up in the old man's luggage that heading to Miami. While there she ends up next door to Elián's relatives, where she meets an anti-Communist bulldog named Bruno who shares his master views. 54 This is clearly to hostile of a place for Martina, so she leaves the house, and this is how she meets a transgender cat named

\footnotetext{
${ }^{2}$ Paul Raffaele, “Forget Jaws, Now it's ... Brains!” Smithsonian Magazine, June 2008. Accessed January 20, 2019, https://www.smithsonianmag.com/science-nature/forget-jaws-now-its-brains-48249580/ 53 "Intrauterine Cannibalism in Sharks." ReefQuest Centre for Shark Research. Accessed January 20, 2019, http://www.elasmo-research.org/education/topics/lh intrauterine cannibalism.htm; Melissa Cristina Márquez, "Shark Cannibalism: It's A Thing And It Just Got Weirder," Forbes, December 29, 2018. Accessed January 20, 2019, https://www.forbes.com/sites/melissacristinamarquez/2018/12/29/shark-cannibalism-its-a-thing-andit-just-got-weirder/\#27d4854f45e1

54 Carmelita Tropicana. "With What Ass Does a Cockroach Sit?"69-92.
} 
Cassandra who "inducts" the roach to the Animal Internet (AI).55 Cassandra finds out that Martina knows Elián, and asks her to do an interview with the boy. The interview happens to occur the same day the U.S. government sends the SWAT Team to escort Elián back to Cuba. Martina goes back to Cube with Elián via his sneaker, and she reunites with Catalina. Martina goes back to the life she described at the beginning of the performance of vocabulary lessons and discussion with Catalina at café con leche.

\section{Layers of Meaning Only Revealed by a Close Reading}

As stated before, when watching the performance of With What Ass Does a Cockroach Sit? (2004) I followed along with the script that is printed in Animal Acts. ${ }^{6}$ There are certain takeaways from Troyano's work that can only be garnered from reading the script and seeing the differences of what happened on stage. The three major ones are the inclusion of the use of choteo that is tied with masculine identity, the construction of her own identity, gender, and sexuality.

Tropicana's performance employs choteo through story building, "mockery, exaggeration, intonation, the body, and word choice." Tropicana is subversively using a Cuban form of humor called choteo to claim importance and to weave history for "queer" Latin and Cuban artists/intellectuals in the mass Fidel Castro caused diaspora.57 Choteo is a form of humor that is idiomatically specific to the popular culture of Cuba, as a way to filter, process, and discuss serious/taboo topics in an irreverently relaxed manner. Choteo features also a unique "leveling tendency" that balances uneven power

\footnotetext{
55 With What Ass Does a Cockroach Sit?/¿ Con Qué Culo Se Sienta la Cucaracha? Performed and written by Carmelita Tropicana. Performed March 22, 2013, Duderstadt Video Studio, https://www.youtube.com/watch?v=813L3yWZYKg.

56 Carmelita Tropicana. "With What Ass Does a Cockroach Sit?" 69-92.

57 Laguna, Aqui Esta' Alvarez Guedes,” 516-7, 26.
} 
dynamics through narrative as seen throughout the performance. $5^{8}$ This humor has incredible power to be subversive politically in the performative arts. This can be seen with Cuban performers like Guillermo Alvarez Guedes, who expressed different ways to think and deal with the loss of home and oppressive Anglo-American culture that required immigrants to be less cubani' a.59 Immigrating at the age of seven to the U.S. such coping mechanisms and identity building methods such as choteo have been a constant rhetorical strategy in Troyano's work. ${ }^{60}$

It should be noted that choteo is largely a male used rhetorical device, as seen evident in the sheer amount of male to female comedians. Troyano as a writer and Tropicana as a performer I think are aware of this. So, by using this technique Troyano not only has a way to address her audience in a cubani adad way that will unite those all affected by the diaspora and educate Americans, but she can also critically address her own communities' ideas, particularly on topics like gender performativity. This effect is even doubled when considering she is a queer woman and the characters she plays in her other works. 61

The construction of Troyano's own identity, gender, and sexuality are under question when she performs and when looking at the script. For instance, the way that Cassandra is written and the lack of appearance in the performance, no one would have known that Cassandra was transgender. One must ask why this is so important of an

${ }^{8}$ It should be noted that choteo's similarities to other forms of humor such as relajo and guachafita have been explored by past scholars. Choteo, though seen as a powerful tool for consolidating Cuban identity outside and inside of its homeland, still has not largely been explored in the diaspora context. Laguna, Aqui“Esta'Alvarez Guedes,” 516-7, 26; Pérez, “Tejanas: Diasporic Subjectivities,” 77-82. Also, see footnote 3 .

59 Laguna, "Aqui' Esta' Alvarez Guedes," 509-531; Vermont Performance Lab, "Carmelita Tropicana / Alina Troyano and Ela Troyano.” https://vermontperformancelab.org/current-artists/41Residencies/carmelita-tropicana.

6o Tropicana, "Carmelita Tropicana Unplugged: An Interview,” 90.

${ }^{61}$ In particularly Tropicana, Pingalito, and Cassandra. 
detail in the story. I will not argue that representation of different groups of people are important, but to my knowledge, Troyano has not written another character that was transgender before or since Cassandra. There must be another reason why this is included. One idea is to suggest that there is no visual marker for someone transgender, that they can fit into the physical signifiers that anyone of their desired gender can. But it is important to note in saying all of this that Troyano has not truly stepped onto the stage as herself. It has always been Tropicana that has stepped onto the stage and performed due to Troyano's own insecurities. ${ }^{62}$ Even in her critically appraised and semi-autobiographical work Milk of Amnesia, Tropicana is playing for the majority of it and Troyano remains largely in the shadows. One of the things that makes performance art stand apart from theatre is that the performance is personal and real to the performer, not a role they take on. ${ }^{63}$ So, what does it mean for someone like Troyano to not fully be herself on stage, and then take on the role of Cassandra that represents a group of people who struggle to be represented and be themselves? The answer to that is not quite so simple, nor do I have space to address this here, but it is an example of a facet of Troyano's work that is only available to study if one studies both her scripts and performances together.

\section{Methodology with With What Ass Does a Cockroach Sit?/¿ Con Qué Culo Se Sienta la Cucaracha?}

The performance of La Cucaracha that I described and analyzed above is one of several times that Alina Troyano agreed to as Tropicana to perform this work in

\footnotetext{
62 Tropicana, "Carmelita Tropicana Unplugged: An Interview,” 90; Troyano, “Author's Introduction,” xiiXxv.

63 See footnote 1 and 12.
} 
different venues. Though one could see from this example that an analysis of her work can be very fruitful to scholars to study, there is unfortunately is a lack of such works doing so. I believe this is because artists like Troyano create a conundrum for the art historical canon in terms of studying performance art.

Art historians study the artistic products of a person, time, place, and culture, and by studying therefore synthesis and analyze the values of all these factors. With performance art, this in general can be quite difficult for several reasons. One, usually when studying art objects the majority of the objects have been made by someone already passed. This first point is even more of a factor when studying performance art because it is generally easier to study said object because, by itself, the passage of time has both obscured and revealed some of the nuances of the context in which it was made. This can make studying said object both easier and in turns more difficult. With performance art, the factors of time and lack of information are usually combined, and this can make any artwork hard to study. More than most for both practice and ideological reasons, performance art likes to keep the documentation of its processes down to a minimal, so there is generally little video recording, photographs, or written accounts. There is also the fact that it has been only a recent development that artists have in general become educated and encouraged as a whole to participate in academia and to challenge readings of their work, and are actually being taken seriously. ${ }^{64} \mathrm{I}$ personally think this last development is a great one, but it does challenge the traditional method of studying art. Second, is that art historians generally have been trained to study objects. Works like Troyano's do not leave the conventional visual

64 See footnote 22. 
object to study. Hence, why performance art like the happenings are more studied than others due to the fact that their by-products have achieved objecthood. Third, I think Troyano's work has not been studied is because her medium is that of performance, not objecthood, such as a painting, as discussed earlier.

My final reason I think Troyano's work hasn't been studied is because she purposefully challenges the art historical canon by virtue of her training, process, and the by-products of her work. She was trained in theatre, so that naturally shows in her process. But again, even in her performance she said, “Besides Kafka’s Metamorphosis, Joan Didion's Miami, and George Orwell's Animal Farm, Perez y Martina was one of inspirations." 65 Clearly, as shown in my analysis there is a literary component to her work, and art historians are not as used to that being as much of a prevalent factor when studying a performance artist. Again, it has only been a recent development for artists to be able to participate in discussions with their work and be literary, such as artists like Coco Fusco. Troyano is beyond what even most other visual artists are in terms of literariness, both in scope of influence and art practice. ${ }^{66}$ The artist's by-product of her performances-scripts-make art historians even more uncomfortable and unsure in how to approach. Gone is the visual image of objecthood to study, and in its place is words.

But, I argue there is a way to study this kind of performance and object even if the artwork changes every time it is performed. I argue that studying these works is much like the same methodology one would use to study a print maker, a graphic artist, or

65 With What Ass Does a Cockroach Sit?/¿ Con Qué Culo Se Sienta la Cucaracha? Performed and written by Carmelita Tropicana. Performed March 22, 2013, Duderstadt Video Studio, https://www.youtube.com/watch?v=813L3yWZYKg.

66 See footnotes 9, 11, 27, and 41. 
even a student who has copied a work in order to study their master artist. One must find the differences between other iterations of the work in order to find significance and meaning. This can be done with a work like Troyano's but instead we must study the script(s), performances, their contexts, and piece them together with the descriptive and analytical skills of an art historian paired with textual tools of English literature.

\section{Conclusion}

As an art historian, I do not know for sure if it has been the right thing to put Troyano's work into the art historical canon by trying to methodologically break down her work, when she clearly avoids direct labels or paths of any kind to herself or her work. But, I hope I have shown more how one can study works like hers, while allowing for the multitude of meanings to stand at the same time, that does some justice to her arts complexity. I think that more works like Troyano's need to be studied because they expand the meaning of what is art, how to study it, and allow the important messages that are uniquely communicated in the performance art medium to reach a wider audience of people. This type of methodology also shows how art historians can be interdisciplinary in their studies while not losing out on the central tools and framework that gives place and meaning to the field of art history as an academic field. And maybe, just perhaps, after reading this essay one can ask themselves and answer the question, With What Ass Does a Cockroach Sit? 
Bibliography:

"A Chronology of the Elian Gonzales Saga." Oregon Public Broadcast: a Division of Public Broadcast Service. Accessed March 16, 2019.

https://www.pbs.org/wgbh/pages/frontline/shows/elian/etc/eliancron.html.

A Performative Lecture: 'Carmelita Can Be a Beast,' o0:52:40, YouTube video, posted by “UCLA Chicano Studies Research Center," June 2, 2014, takes place on April 18, 2014. Performed by Carmelita Tropicana. Recorded At the UCLA Chicano Studies Research Center. Accessed February 20, 2019, https://www.youtube.com/watch?v=P5DTW229EQE.

Anzaldúa, Gloria. Borderlands/La Frontera. The New Mestiza. (Spinsters/Aunt Lute Book Company, San Francisco, 1987.)

“Can Same-Sex Couples Adopt?” American Adoptions. Accessed January 15, 2019. https://www.americanadoptions.com/adopt/LGBT adoption.

Carmelita Cabaret Hemi 2013. Uploaded by the Hemispheric Institute, New York University. Performed by Carmelita Tropicana. Edited by Victor Bautista. Performed at SP Escola de Teatro. Performed on January 19, 2013. Accessed January 15, 2019. https://hemisphericinstitute.org/en/enc13trasnocheo/item/2132-enc13-trasnocheo-carmelita.html.

Carmelita Tropicana and Ela Troyano: $R+D$ for Schwanze-Beast." 00:05:36. YouTube video. Uploaded by “vplsara," on July 2, 2015. Accessed February 20, 2019. https://vermontperformancelab.org/current-artists/41-Residencies/carmelitatropicana.

Carmelita Tropicana Reads for Memories That Smell Like Gasoline: Reading David Wojnarowicz. oo:08:43. Vimeo video. Posted by “Visual AIDS.” In October 2018. Performed by Carmelita Tropicana. Filmed and edited by Kyle Croft. This program was organized in collaboration with the Whitney Museum of American Art. Accessed January 15, 2019. https://vimeo.com/292723134.

Carr, C. "Loisaida Talking Pictures. Ela Troyano," "The Queer Frontier: Holly Hughes and Carmelita Tropicana," and "The Lady Is a Dick: The Dyke Noir Theater of Holly Hughes." On Edge: Performance at the End of the Twentieth Century. (Wesleyan University Press, 1993), 78-83, 84-87, and 132-137. 
Case, Sue-Ellen. "Seduced and Abandoned: Chicanas and Lesbians in Representation." In Negotiating Performance, edited by Diana Taylor and Juan Villegas. (Duke University Press, 1994), 88-101.

Cespedes, Karina Lissette. "Bombera on Stage: Carmelita Tropicana Speaking in Tongues Against History, Madness, Fate, and the State.” In Hispanic and U.S. Latina Lesbian Expression. Tortilleras, edited by Lourdes Torres and Inmaculada Pertusa. (Temple University Press, 2003),147-158.

Chaka, Kyle. “WTF is...Performance Art?” Hyperallergic. May 24, 2011. Accessed February 20, 2019. https://hyperallergic.com/25076/wtf-is-performance-art/

Chaudhuri, Una. "Animal Acts for Changing Times, 2.0: A Field Guide to Interspecies Performance.” In Animal Acts. Performing Species Today, Una Chaudhuri and Holly Hughes. (University of Michigan Press, 2014), 1-12.

Chowdhry, Maya. "Living Performance." In Acts of Passion: Sexuality, Gender, and Performance, edited by Maya Chowdhry and Nina Rapi. (The Haworth Press, Inc., New York and London, 1998), 9-20.

Danielson, Marivel T. "Our Art is Our Weapon: Identity and Representation in Queer U.S. Latina Creativity.” (PhD Dissertation, University of Michigan, 2004.)

Davy, Kate. Triangulations. Lesbian/Gay/Queer $\mathbf{\Delta}$ Theater/Drama/Performance. Lady Dicks and Lesbian Brothers: Staging the Unimaginable at the WOW Café, edited by Jill Dolan and David Román. (University of Michigan, 2010.)

Dolores Costa, Marí a. "Latina Lesbian Writers and Performers: An Overview." In Latina Lesbian Writers and Performers, edited by Mari' a Dolores Costa. (Haworth Press or Journal of Lesbian Studies. Vol 7, No. 3, 2003), 5-26.

Edwards, Cliff. "When I Wish Upon a Star," by Leigh Harline, Ned Washington, in Pinocchio, Walt Disney Studios, 1940.

Fusco, Coco. "Pura Bicultural: An Introduction," "Pan American Postnationalism: Another World Order," "Passionate Irreverence: The Cultural Politics of Identity," "The Other History of Intercultural Performance," and "Who's Doin' the Twist? Notes Toward a Politics of Appropriation." In English is Broken Here. (The New Press: New York City, 1995), vii-xi, 21-78. 
Fusco, Coco. "Introduction: Latin America Performance and the Reconquista of Civil Space.” In Corpus Delicti. Performance Art of the Americas, edited by Coco Fusco. (Routledge, 2000), 1-22.

Fusco, Coco. "Preface," "The bodies that were not ours," "Hustling for dollars: jineteras in Cuba," "Bridge over troubled waters: and view from the bridge four years on," "El Último Deseo (the last wish): a performance for Cuba," and "El Evento Suspendido (the postponed event): a performance for Cuba." In The Bodies That Were Not Ours and Other Writings. Routledge, 2001), xiii-xvii, 8-17, 137-155, 163-166.

García Canlini, Ne' stor. Translated by Bruce Campbell. "Introduction: Hybrid Cultures in Globalized Times." In Hybrid Cultures in Globalized Times. (University of Minnesota, 2005), xxiii-xlvi.

Garland, Leah. "Introduction" and "Alina Troyano's Performance Autobiography: The Carmelita Solution in Milk of Amnesia/Leche de Amnesia." In Contemporary Latina/o Performing Arts of Moraga, Tropicana, Fusco, and Bustamante. Peter Lang Publishing, New York, 2009), 1-10, 45-66.

Gil-Gomez, Ellen M. "Performing La Mestiza. Textual Representations of Lesbians of Color and the Negotiation of Identities." In Literary Criticism and Cultural Theory: The Interaction of Text and Society, edited by William E. Cain. (Taylor \& Francis, London, 2000), 3-38, 135-166.

Go' mez-Peña, Guillermo. "The Multicultural Paradigm: An Open Letter to the National Arts Community." In Negotiating Performance, edited by Diana Taylor and Juan Villegas. (Duke University Press, 1994), 17-29.

Interview with Carmelita Tropicana. 00:37:30. 2001. Video interview uploaded by the New York University, Hemispheric Institute Digital Video Library as part of the Encuentro: Memory, Atrocity, and Resistance collection. Performed by Carmelita Tropicana. Recorded in Monterrey, Mexico in 2001. Accessed January 20, 2019. http://hidvl.nyu.edu/video/2547db54.html.

"Intrauterine Cannibalism in Sharks." ReefQuest Centre for Shark Research. Accessed January 20, 2019. http://www.elasmoresearch.org/education/topics/lh intrauterine cannibalism.htm.

Khan Academy. “What is performance art?” The Tate. 2015. Accessed February 20, 2019. https://www.khanacademy.org/partner-content/tate/participationperformance/performance/a/what-is-performance-art. 
Londõno, Ernesto. "Increasingly Visible, Cuba's Elián González Champions Island's Government. ”July 9, 2015. New York Times. Accessed March 16, 2019. https://takingnote.blogs.nytimes.com/2015/07/09/increasingly-visible-cubaselian-gonzalez-champions-islandsgovernment/?rref=collection\%2Ftimestopic\%2FGonzalez\%2C\%2oElian\&action= click\&contentCollection=timestopics\&region=stream\&module=stream unit\&ver $\underline{\text { sion}=l a t e s t \& c o n t e n t P l a c e m e n t=2 \& p g t y p e}=$ collection .

Lopes, Mark Hugo and Ana Gonzales-Barrera and Jens Manuel Krogstad. “2. Latinos and discrimination: More Latinos have Serious Concerns about their Place in America under Trump." Pews Research Center: Hispanic Trends. October 25, 2018. Accessed January 15, 2019.

https://www.pewhispanic.org/2018/10/25/latinos-and-discrimination/.

Lo' pez-Craig, Tonya. "The Role of Carmelita Tropicana in the Performance Art of Alina Troyano." In Latina Lesbian Writers and Performers. (Haworth Press or Journal of Lesbian Studies. Vol 7, No. 3, 2003), 47-56.

Manifest Destino. 25:44. Uploaded by the Hemispheric Institute, New York University. Performed by Carmelita Tropicana. Edited by Victor Bautista. At Encuentro Location (Montréal):Phi Centre, Rialto Theatre, Sala Rossa. On June 22, 24, and 28, 2014. Accessed November 21, 2018. https://hemisphericinstitute.org/en/enc14-trasnocheo/item/2441-enc14trasnocheo-tropicana-destino.html.

Márquez, Melissa Cristina. "Shark Cannibalism: It's A Thing And It Just Got Weirder." Forbes. December 29, 2018. Accessed January 20, 2019. https://www.forbes.com/sites/melissacristinamarquez/2018/12/29/sharkcannibalism-its-a-thing-and-it-just-got-weirder/\#27d4854f45e1

Marrero, Marí a Teresa. "Public Art, Performance Art, and the Politics of Site.” In Negotiating Performance, edited by Diana Taylor and Juan Villegas. (Duke University Press, 1994), 102-120.

Melzer A. "Dada Performance at the Cabaret Voltaire." In ARTFORUM (U.S.A. 12, no. 3, 1973): 74-78.

"Memories That Smell Like Gasoline: Reading David Wojnarowicz," Whitney American Museum of Art. Accessed January 15, 2019. visualaids.org/events/detail/memories-that-smell-like-gasoline.

Mesa-Bains, Amalia. "Domesticana: the Sensibility of Chicana Rasquache." In Aztlan: A Journal of Chicano Studies. (Los Angeles, 24, no. 2, Fall, 1999): 157-167. 
Muñoz, Jose' Estban. "Choteo/Camp Style Politics: Carmelita Tropicana's Performance of Self-Enactment." In Women and Performance: A Journal of Feminist Theory. (7, no. $2-8$, no. 1,1995$): 38-51$.

Muñoz, Jose' Estban. "No es fa' cil: Notes on the Negotiation of Cubanidad and Exilic Memory in Carmelita Tropicana's Milk of Amnesia." In Drama Review (39, no.3, 1995): 76-82.

Muñoz, Jose' Estban. "Preface," "Introduction. Performing Disidentifications," "Sister Acts. Ela Troyano and Carmelita Tropicana," "Performing Disidentity. Disidentity as a Practice of Freedom," and "Latina Performance and Queer Worldmaking; or, Chusmeri ' $a$ at the End of the Twentieth Century." In Disidentifications: Queer of Color and the Performance Politics. (Minneapolis: University of Minnesota Press, 1999), ix-xiv, 1-34, 119-142, 161-200.

Musing Muses. 00:09:59. YouTube video. Posted by “TheFeMUSEum," on September 18, 2011. Recorded at Dixon Place, on May 29, 2011. Accessed January 15, 2019. https://www.youtube.com/watch?v=3TK1VQitd-M.

Musing Muses Carmelita Tropicana. 00:04:57. YouTube video. Posted by "TheFeMUSEum," on September 18, 2011. Recorded at Dixon Place, on May 29, 2011. Accessed January 15, 2019. https://www.youtube.com/watch?v=zUZEdkcJiuA\&list=PL7F36C26374B35422 \&index $=3$.

Noriega, Chon A. "Editor's Note." In I, Carmelita Tropicana: Performing Between Cultures. Bluestreak, edited by Chon A Noriega. (Beacon Press, 2000), ix-xii.

Pérez, Emma. "Tejanas: Diasporic Subjectivities and Post-Revolution Identities." In The Decolonial Imaginary: Writing Chicanas into History. (Indiana University Press, 1999), 77-82.

Performing Species: What Can Animal Studies and Theatre/Performance Studies Teach Each Other? 01:32:59, YouTube video. Uploaded by "NYUAD Institute," on August 7,2015. Recorded on September 19, 2014. Accessed February 20, 2019. https://www.youtube.com/watch?v=7J49hw46wmo.

Raffaele, Paul. "Forget Jaws, Now it's ... Brains!” Smithsonian Magazine. June 2008. Accessed January 20, 2019. https://www.smithsonianmag.com/sciencenature/forget-jaws-now-its-brains-48249580/.

Rapi, Nina. "Representing the 'Real.”' In Acts of Passion: Sexuality, Gender, and Performance, edited by Maya Chowdhry and Nina Rapi. (The Haworth Press, Inc., New York and London, 1998), 1-8. 
Reilly, Mollie. "Same-Sex Couples Can Now Adopt Children In All 5o States."

Huffington Post. March 31, 2016. Accessed January 20, 2019.

https://www.huffpost.com/entry/mississippi-same-sexadoption n 56fdb1a3e4b083f5c607567f.

Santa Maria, Cara. “Is Sex For Pleasure Uniquely Human?” Huffington Post. January 13, 2012. Accessed January 20, 2019. https://www.huffpost.com/entry/sex-forpleasure $\mathrm{n} 1090811$.

Savran, David. "Queer Theater and the Disarticulation of Identity.” In The Queerest Art: Essays on Lesbian and Gay Theater, edited by Alisa Solomon and Framji Minwalla. (New York University Press, 2002), 152-167.

Sergio Laguna, Alberto. "Aqui' Esta' Alvarez Guedes: Cuban choteo and the politics of play.” Latino Studies, (Vol. 8, 4): 509-531.

Senelick, Laurence. “The Queer Root of Theater.” In The Queerest Art: Essays on Lesbian and Gay Theater, edited by Alisa Solomon and Framji Minwalla. (New York University Press, 2002), 21-39.

Sharpsteen, Ben and Hamilton Luske. Pinocchio, February 23, 1940. (Los Angeles, Walt Disney Studios and RKO Radio Pictures.)

Taylor, Diana. "Opening Remarks." In Negotiating Performance, edited by Diana Taylor and Juan Villegas. (Duke University Press, 1994), 1-16.

The Muses. 00:13:38. Uploaded by the New York University, Hemispheric Institute. Performed by Carmelita Tropicana. Edited by Victor Bautist. Performed at Sesc Vila Mariana - Acesso Balcão do Teatro on January 16, 2013. Accessed November 21, 2018.https://hemisphericinstitute.org/en/enc13-performances1/item/1999enc13-carmelita-muses.html.

Traub, Valerie. "Setting the Stage behind the Seen: Performing Lesbian History." In The Queerest Art: Essays on Lesbian and Gay Theater, edited by Alisa Solomon and Framji Minwalla. (New York University Press, 2002), 55-105.

Tropicana, Carmelita. "Carmelita Tropicana Unplugged.” Interview by David Román, The Drama Review (39, no.3, 1995): 84-90.

Tropicana, Carmelita. “Chicas 2000: an excerpt.” In Corpus Delicti. Performance Art of the Americas, edited by Coco Fusco. (Routledge, 2000), 41-42. 
Tropicana, Carmelita. “Goodnight Irene: An Endnote.” In The Queerest Art: Essays on Lesbian and Gay Theater, edited by Alisa Solomon and Framji Minwalla. (New York University Press, 2002), 261-266.

Cry a la Jack. 00:16:19. An video interview of Carmelita Tropicana. Carmelita Tropicana Collection. Hemispheric Institute Digital Video Library, New York University. Uploaded 2005. Recorded at the Grimm Rosenfeld Gallery, New York, NY. Accessed January 15, 2019. http://hidvl.nyu.edu/video/sno2v98g.html.

Tropicana, Carmelita. "Carmelita Tropicana." Carmelita Tropicana professional website, accessed November 20, 2018. http://carmelitatropicana.com/.

Tropicana, Carmelita. "With What Ass Does a Cockroach Sit?/¿ Con Que' Culo Se Sienta la Cucaracha?” In Animal Acts. Performing Species Today, Una Chaudhuri and Holly Hughes. Commentary by Lawrence La Fountain-Stokes. (University of Michigan Press, 2014), 69-92.

Troyano, Alina with Uzi Parnes and Ela Troyano. I, Carmelita Tropicana. Performing Between Cultures. Bluestreak, edited by Chon A. Noriega. (Beacon Press, 2000.)

Torres, Lourdes. "Introduction.” In Hispanic and U.S. Latina Lesbian Expression. Tortilleras, edited by Lourdes Torres and Inmaculada Pertusa. (Temple University Press, 2003), 1-18.

Weaver, Lois. "Performing Butch/Femme Theory.” In Acts of Passion: Sexuality, Gender, and Performance. (The Haworth Press, Inc.,New York and London, 1998), 187-200.

"Welcome to the Pura Belpré Award home page!” Association for Library Service to Children, A Division of The American Library Association, http://www.ala.org/alsc/awardsgrants/bookmedia/belpremedal.

"Why are people and dolphins the only mammals that have sex for pleasure?" University of California. January 20, 2006. Accessed March 15, 2019. http://scienceline.ucsb.edu/getkey.php?key=1132.

Wilkinson, Chris. "Noises off: What's the Difference Between Performance Art and Theatre?” The Guardian. July 20, 2010. Accessed February 20, 2019. https://www.theguardian.com/stage/theatreblog/2010/jul/20/noises-offperformance-art-theatre.

With What Ass Does a Cockroach Sit?/¿ Con Que' Culo Se Sienta la Cucaracha? YouTube video, 25:20. Posted by “umichpress." Uploaded February 3, 2014. 
Directed by David Schweizer. Performed and written by Carmelita Tropicana. Performed March 22, 2013, Duderstadt Video Studio. Premiered at the INTAR Theatre in 2004. Accessed November 20, 2018.

https://www.youtube.com/watch?v=813L3yWZYKg.

Ulaby, Nedua. "How NYC's First Puerto Rican Librarian Brought Spanish To The

Shelves.” September 8, 2016. National Public Radio. Accessed February 15, 2019. https://www.npr.org/2016/o9/08/492957864/how-nycs-first-puerto-ricanlibrarian-brought-spanish-to-the-shelves. 